\title{
PENURUNAN KADAR TRIGLISERIDA TIKUS PUTIH WISTAR JANTAN (Rattus novergicus) HIPERLIPIDEMIK YANG DIBERI EKSTRAK TERPUIFIKASI BATANG GALING (Cayratia trifolia L. Domin.)
}

\section{REDUCTION OF TRIGLICERID LEVELS WHITE MALE RATS WISTAR (Rattus novergicus) HYPERLIPIDEMIC WHICH IS PROVIDED BY EXTRACT PURIFIED OF GALING STEAM (Cayratia trifolia L. Domin.)}

\author{
Muhammad Ilyas $\mathbf{Y}^{1 *)}$, Apriyanto ${ }^{1}$, Claudia Montana ${ }^{1}$, Fadhliyah Malik ${ }^{2}$, \\ Irma $^{3}$, Sri Susanty ${ }^{4}$ \\ ${ }^{1}$ Politeknik Bina Husada Kendari, Jl. Sorumba No.17 Kendari 93117 \\ ${ }^{2}$ Fakultas Farmasi, Universitas Halu Oleo, Jl. H.E.A Mokodompit Kendari 93232 \\ ${ }^{3}$ Fakultas Kesehatan Masyarakat, Universitas Halu Oleo, Jl. H.E.A Mokodompit Kendari \\ 93232 \\ ${ }^{4}$ Prodi Ilmu Keperawatan, Universitas Halu Oleo, Jl. H.E.A Mokodompit Kendari 93232
}

Summited : 29 Januari 2020 Reviewed : 06 Februari 2020 Accepted : 07 Maret 2020

\begin{abstract}
ABSTRAK
Trigliserida adalah salah satu jenis lemak yang terdapat dalam darah dan berbagai organ tubuh. Kadar trigliserida yang tinggi dan defisiensi lipase dapat meningkatkan faktor resiko penyakit jantung koroner. Tumbuhan galing (Cayratia trifolia L. Domin.) merupakan tumbuhan yang mengandung senyawa bioaktif diantaranya adalah senyawa flavonoid yang berpotensi mampu menurukan kadar trigliserida dalam darah. Tujuan penelitian yaitu untuk mengetahui penurunan kadar trigliserida tikus putih wistar jantan (Rattus novergicus) yang mengalami hiperlipidemia setelah pemberian ekstrak terpurifikasi batang galing. Jenis penelitian ini adalah penelitian eksperimen yang terdiri dari 18 ekor tikus putih jantan yang dibagi dalam tiga kelompok perlakuan ekstrak terpurifikasi batang galing, kontrol negatif dan kontrol positif masing-masing 6 ekor tikus putih. Hasil penelitian menunjukan adanya penurunan kadar trigliserida pada tikus putih wistar jantan yang mengalami hiperlipidemia setelah pemberian ekstrak terpurifikasi batang galing $500 \mathrm{mg} / \mathrm{kg}$ BB yang tidak berbeda signifikan dengan kontrol positif ( $p>0.05$ ).
\end{abstract}

Kata Kunci : Trigliserida, purifikasi, Cayratia trifolia L.Domin., Rattus novergicus

\begin{abstract}
Triglycerides are one type of fat found in the blood and various organs of the body. High triglyceride levels and lipase deficiency can increase risk factors for coronary heart disease. Cayratia trifolia L. Domin plants is plants that contain bioactive compounds such as flavonoids which have the potential to reduce triglyceride levels in rats. The purpose of this study was to determine the decrease in triglyceride levels with purified extract of Cayratia trifolia L. Domin stem in male wistar white rats (Rattus novergicus) which experienced hyperlipidemia. This type of research is an experimental study consisting of 18 white rats divided into three treatment groups. Where each treatment is a group of Cayratia trifolia $\mathrm{L}$ Domin stem purified extract, negative control group and positive control group, each of
\end{abstract}


which consists of 6 white rats is considered as an application. The results showed a decrease in triglyceride levels in male wistar rats that experienced hyperlipidemia after giving of purified extracts of $500 \mathrm{mg} / \mathrm{kgBW}$ stem that were not significantly different from positive controls ( $\mathrm{p}>0.05)$.

Keyword: Triglyceride, purified, Cayratia trifolia L. Domin, Rattus novergicus

\section{Penulis Korespondensi :}

Muhammad Ilyas Y

Politeknik Bina Husada Kendari Jl. Sorumba No.17 Kendari 93117

Email : ilyasyusufmuhammad.apt@gmail.com / 081394035046

\section{PENDAHULUAN}

Kolesterol merupakan bahan lemak yang digunakan oleh tubuh untuk memelihara organ-organ yang struktur selnya berbasis lemak, misalnya hati, dan otak, namun, kita perlu menjaga kadarnya di dalam darah dalam batas tertentu. Jika menjadi terlalu tinggi, kelebihan kolesterol akan ditimbun di dinding pembuluh darah, bersamaan dengan lemak/lipid (Judo, 2010). Penimbunan kolesterol di dinding pembuluh darah, menimbulkan plak, sehingga berdampak dinding pembuluh darah mengalami penyempitan, keras dan kaku sehingga ruangan untuk aliran darah menyempit, tekanan darah naik dan berakibat pada serangan jantung dan pendarahan otak (Ilyas, 2017).

Lemak dalam zat makanan umumnya terdiri dari tiga gugus asam lemak dengan gliserol dikenal sebagai trigliserida. Trigliserida adalah salah satu jenis lemak yang terdapat dalam darah dan berbagai organ tubuh (Zou dan Wei, 2005). Trigliserida dimanfaatkan dalam tubuh terutama untuk menyediakan energi untuk berbagai proses metabolik. Trigliserida terbentuk dari gliserol dan lemak dari makanan dengan bantuan hormon insulin atau kelebihan dari kalori akibat makan berlebihan (Skeggs dan Morton, 2002).

Kelebihan kalori akan diubah menjadi trigliserida dan disimpan sebagai lemak dibawah kulit. Kadar trigliserida yang tinggi dan defisiensi lipase dapat meningkatkan faktor resiko penyakit jantung koroner. Peningkatan resiko tersebut dibuktikan terutama melalui penurunan HDL (Judo, 2010). Kadar trigliserida yang menurun dapat dihubungkan dengan resiko penyakit jantung koroner (PJK) yang lebih rendah (Zou dan Wei, 2005).

Banyaknya bahaya atau resiko yang diakibatkan, maka itu diperlukan upaya untuk menanggulanginya misalnya dengan menggunakan obat hipolipidemik (Dewi, 2013). Obat hipolipidemik akan menimbulkan ketergantungan bagi penggunanya dan bila digunakan secara berkelanjutan obat ini akan mengakibatkan gangguan fungsi organ lain seperti yang dilaporkan oleh American Medical Association (AMA). Adanya beberapa efek samping yang merugikan dapat ditimbulkan obat hipolipidemik, sehingga diperlukan usaha untuk mencari alternatif lain yang lebih aman, misalnya penggunaan tanaman yang memiliki potensi hipolipidemik. Tanaman berpotensi hipolipidemik merupakan tanaman yang dapat menurunkan kadar lemak dalam darah karena kandungan senyawa aktif yang dimilikinya (Dewi, 2013).

Salah satu tumbuhan di Indonesia yang dijadikan obat tradisional adalah tumbuhan galing (Cayratia trifolia L.Domin). Tumbuhan galing mengandung berbagai macam golongan senyawa seperti alkaloid, flavonoid, polifenol, tanin, terfenoid/steroid, minyak lilin kuning, kaemferol, myricetin, quercetin, triterfen, karbohidrat, dan epifriedelanol (Roat C dkk., 2008; Kumar dkk., 2012). Pada daun galing mengandung senyawa stilbenes (piceid, resveratol, viniferin, ampelopsin), batang, daun dan akar, mengandung hydrocyanic acid, delphinidin, beberapa golongan flavoniod seperti cyanidin,terutama pada daun dan buahnya mengandung kalsium oksalat (Kumar dkk., 2012; Singh dkk., 2012; Yusuf dkk.,2018). Penelitian sebelumnya menunjukkan tumbuhan galing memiliki efek sebagai 
antihiperlipidemia pada mencit Balb/C (Ilyas, 2017), antioksidan, antidiabetik (Yusuf dkk., 2018) dan imunomodulator (Ilyas, 2019).

Berdasarkan latar belakang yang telah dijabarkan diatas, penelitian ini dilakukan dengan tujuan untuk mengetahui kadar trigliserida pada tikus putih wistar jantan (Rattus norvegicus) yang hiperlipidemik setelah pemberian ekstrak terpurifikasi batang galing (Cayratia trifolia L.Domin).

\section{METODE PENELITIAN}

\section{Alat dan Bahan}

Alat-alat yang digunakan pada penelitian ini adalah batang pengaduk, kandang tikus, timbangan analitik (percisa), botol minum tikus, spuit $1 \mathrm{~mL}$ (One Made ${ }^{\circledR}$ ), vaccum rotary evaporator (IKA-Werke RV 05 Germany $^{\circledR}$ ), maserator, lumpang dan alu, alat-alat gelas $\left(\right.$ pyrex $^{\circledR}$ ) glukometer, Photometer $5010 \mathrm{V5}^{+}$, sonde oral.

Bahan-bahan yang digunakan dalam penelitian ini yaitu akuadest, etanol 96\%, nHeksan, ekstrak terpurifikasi batang galing, kain flanel, Na-CMC 0,5\%, strip trigliserida nesco, atorvastatin $20 \mathrm{mg}$, propiltiourasil (PTU), makanan diet tinggi lemak (MDTL), tikus putih wistar jantan (Rattus novergicus), kuning telur puyuh, reagen kit trigliserida (human).

\section{Jalannya Penelitian}

\section{Penyiapan Sampel}

Pengumpulan sampel batang galing (Cayratia trifolia L.Domin) dengan kriteria tumbuhan galing yang memiliki bunga dan atau buah, dengan mengambil batang dari dahan pertama sampai ke tanah pada waktu pagi hari. Batang galing di sortasi basah dengan tujuan untuk memisahkan kotoran-kotoran atau bahan-bahan asing. Batang galing kemudian dicuci dengan air mengalir, pencucian bertujuan menghilangkan kotoran-kotoran pada simplisia. Seluruh bagian batang galing dilakukan perajangan untuk mempermudah proses pengeringan. Sampel batang dikeringkan dengan cara dijemur di bawah sinar matahari yang dilapisi kain hitam kemudian dihaluskan dengan diblender hingga diperoleh serbuk simplisia.

\section{Ekstraksi}

Ditimbang serbuk simplisia batang galing, dimasukan ke dalam bejana maserasi. Ditambahkan pelarut etanol $96 \%$ dengan perbandingan 1 bagian sampel berbanding dengan 7,5 bagian pelarut. Ditutup dan didiamkan selama 3x24 jam pada temperatur kamar terlindungi dari cahaya sambil sesekali diaduk. Hasil ekstraksi disaring menggunakan kain flanel kemudian dilanjutkan dengan penyaringan menggunakan kertas saring dan ditampung dalam bejana botol penampung. Ekstrak yang diperoleh dikumpul dan diuapkan kemudian dikentalkan menggunakan alat (Vaccum Rotary Evaporator). Ekstrak yang diperoleh ditimbang beratnya kemudian disimpan pada tempat yang terlindungi dari cahaya (Pratiwi, 2016).

\section{Purifikasi Ekstrak}

Ditimbang ekstrak kental dilarutkan dalam etanol dengan perbandingan 1:1 (1 gram ekstrak kental dalam $1 \mathrm{~mL}$ pelarut) dan dimasukkan ke dalam corong pisah. Ditambahkan $100 \mathrm{~mL}$ N-heksan, setelah itu digojog selama 10-15 menit dan didiamkan sampai terbentuk dua fase yang terpisah. Diambil fase bawah dengan cara dialirkan, kemudian dimasukan kembali ke dalam corong pisah kemudian ditambahkan $100 \mathrm{~mL}$ n-Heksan dan fase atas ditampung diwadah. Kemudian dilakukan pengulangan diatas hingga fase atas yang diperoleh berwarna bening. Kemudian diuapkan dalam waterbath hingga diperoleh ekstrak kental (Malik, 2014).

\section{Pembuatan Suspensi Atorvastatin}

Ditimbang satu per satu tablet atorvastatin $20 \mathrm{mg}$ sebanyak 10 tablet ditimbangan digital. Dihitung berat rata-rata tablet, digerus tablet atorvastatin, kemudian ditimbang sebanyak 0,37 gram serbuk atorvastatin. Disuspensikan dengan menambahkan $30 \mathrm{~mL}$ larutan Na.CMC $0,5 \%$ aduk hingga homogen. 


\section{Penentuan Dosis Propiltiourasil}

Dosis propiltiourasil (PTU) yang digunakan sebanyak $1,8 \mathrm{mg} / \mathrm{g}$ BB tikus. Dosis propiltiourasil dikonversi ke dosis tikus putih menjadi $0,018 \mathrm{mg} / \mathrm{g} \mathrm{BB}$ (Nofianti, 2015).

\section{Penyiapan Makanan Diet Lemak Tinggi (MDTL)}

Komposisi dari MDTL yaitu kuning telur puyuh $10 \mathrm{~mL} / \mathrm{kgBB}$, selanjutnya kuning telur puyuh diberikan pada badan hewan coba, kemudian pemberian dilakukan secara peroral (Nofianti, 2015).

\section{Penyiapan Hewan Uji}

Hewan uji diaklimatisasi selama satu minggu dengan tujuan untuk mengadaptasikan hewan uji dengan lingkungan baru. Setiap hewan uji diberi makan dan minum serta dilakukan pengamatan berat badan dengan cara menimbang semua hewan uji pada setiap kelompok perlakuan. Penelitian ini digunakan tikus putih sebagai hewan uji karena hal ini berdasaran pertimbangan susunan anatomi fisiologi tikus memiliki kemiripan dengan manusia, mudah ditangani, mudah didapat, mudah dalam pemeliharaan, dapat beradaptasi dengan baik (Susanti dkk., 2014). Penelitian ini telah mendapatkan persetujuan kelaikan etik No : 2359/UN29.20/PPM/2018 yang dikeluarkan oleh Komisi Etik Penelitian Kesehatan Universitas Halu Oleo.

\section{Perlakuan Hewan Uji}

Disiapkan alat dan bahan yang digunakan, sebanyak 18 ekor hewan uji (tikus) dibagi menjadi tiga kelompok uji masing-masing kelompok terdiri dari 6 ekor tikus. Masingmasing berat tikus di timbang, diadaptasikan dan dipuasakan 8 jam. Kemudian diukur kadar trigliserida awal tikus dengan glukometer (NESCO). Semua tikus diberikan makanan diet tinggi lemak (MDTL) dengan dosis $10 \mathrm{~mL} / \mathrm{Kg} \mathrm{BB}$ dan PTU $1,8 \mathrm{mg} / 200 \mathrm{~g}$ BB perhari selama 1 minggu. Berdasarkan penelitian Nofianti dkk (2015) bahwa pemberian 1 minggu MDLT dapat meningkatkan kadar trigliserida tikus putih Wistar. Dilakukan pengukuran kadar trigliserida untuk mengetahui peningkatan kadar trigliserida tikus setelah induksi MDTL. Tikus yang mengalami hipertrigliserida dikelompokan secara acak menjadi tiga kelompok yang terdiri dari kelompok I diberikan $\mathrm{Na} \mathrm{CMC} 0,05 \%$ sebagai kontrol negatif, kelompok II diberikan suspensi atorvastatin $0,149 \mathrm{mg} / \mathrm{kgBB}$ sebagai kontrol positif dan kelompok III diberikan ekstrak purifikasi batang galing $500 \mathrm{mg} / \mathrm{kgBB}$.Tiap tikus diberi sediaan sesuai kelompok perlakuan melalui oral dengan menggunakan sonde oral sekali sehari selama 7 hari. Pada hari ke-8 setelah perlakuan, semua tikus diukur kadar trigliserida menggunakan Photometer5010V5 ${ }^{+}$.

\section{Pengukuran kadar trigliserida}

Seluruh tikus diambil darahnya sebanyak $2 \mathrm{~mL}$ melalui vena bagian leher lalu dimasukan ke dalam tabung EDTA, didiamkan selama 30 menit kemudian disentrifugasi pada kecepatan $3000 \mathrm{rpm}$ selama 10 menit, lapisan plasma diambil dengan menggunakan mikropipet dimasukkan ke dalam wadah yang bersih dan selanjutnya dilakukan pemeriksaan kadar trigliserida. Pemeriksaan kadar trigliserida menggunakan metode glycerol-3-phosfate oxidase-phenol aminophenazone (GPO-PAP). Metode ini menggunakan prinsip oksidasi dan hidrolisis enzimatis. Sebanyak $10 \mu \mathrm{L}$ plasma direaksikan dengan reagen kit trigliserida sebanyak $1000 \mu \mathrm{L}$ lalu dikocok dan diinkubasi pada suhu ruang selama 10 menit sampai terbentuk warna merah muda. Standar dibuat dengan mencampurkan $10 \mu \mathrm{L}$ standar trigliserida dan $1000 \mu \mathrm{L}$ reagen kit trigliserida. Blanko dibuat dari $1000 \mu \mathrm{L}$ reagen kit pereaksi tanpa penambahan apapun. Serapan sampel diukur dengan Photometer 5010V5 ${ }^{+}$ pada panjang gelombang $546 \mathrm{~nm}$ (Lynch's, 1993; Nofianti, 2015).

\section{HASIL DAN PEMBAHASAN}

Pengujian kadar trigliserida ekstrak terpurifikasi batang galing (Cayratia trifolia L.Domin) pada tikus putih wistar (Rattus novergicus) menggunakan penginduksi MDTL (kuning telur puyuh $10 \mathrm{~mL} / \mathrm{Kg} \mathrm{BB}$ ) dan propiltiourasil (PTU). Menurut Nofianti dkk., (2015) pemberian kuning telur puyuh $10 \mathrm{~mL} / \mathrm{kg}$ BB dapat meningkatkan kadar trigliserida pada hewan uji model hiperlipidemia. Tiap kuning telur puyuh mengandung kolesterol sekitar 250 mg. Selain pemberian kuning telur puyuh sebagai MDTL, juga dilakukan penginduksian 
dengan PTU untuk mempercepat peningkatan kadar hiperlipidemia pada tikus, dimana PTU merupakan derivat pirimidin yang berkhasiat sebagai tiroistatik., bekerja sebagai antitiroid yang menghambat sel-sel tiroid pada tikus, sehingga produksi hormon tiroid terhambat dan mengakibatkan tikus mengalami hipotiroidisme. Pengaruh langsung hipotiroidisme pada metabolisme lipoprotein adalah peningkatan kadar kolesterol terutama LDL kolesterol yang diakibatkan oleh penekanan metabolik pada reseptor LDL, sehingga kadar kolesterol LDL akan meningkat (Guyton, 1997). Selain itu PTU juga dapat mengacaukan fungsi Apo-A-I dan Apo-A-IV, kedua komponen tersebut berfungsi menghantarkan kolesterol HDL dari jaringan ke hati (Shin dan Osborne, 2003). PTU juga dapat menekan aktivitas lipoprotein lipase sehingga trigliserida tidak dapat terpecah menjadi asam lemak bebas dan gliserol. Hal ini mengakibatkan kadar trigliserida meningkat (Pykalisto dkk., 1976). Penginduksi telur puyuh dilakukan sekali sehari yaitu pada siang hari, diberi kuning telur puyuh 1,8 mL/ekor dengan campuran PTU. Pemberian MDTL dan PTU di lakukan selama 7 hari kemudian pada hari ke 8 dilakukan pemeriksaan kadar trigliserida dengan rata-rata 241,1667 mg/dL. Setelah hewan uji mengalami hiperlipidemia, hewan uji kemudian diberi terapi ekstrak terpurifikasi batang galing dosis $500 \mathrm{mg} / \mathrm{kg}$ BB dan atorvastatin $0,149 \mathrm{mg} / \mathrm{kg} \mathrm{BB}$ sebagai kontrol positif.

Pengukuran kadar trigliserida dilakukan sebayak tiga kali, yaitu pengukuran pertama bertujuan untuk mengetahui kadar awal trigliserida, pengukuran kedua pada hewan uji yang telah mengalami hiperlipidemia bertujuan untuk mengetahui kadar trigliserida pada hewan uji setelah diinduksi MDLT (kuning telur puyuh dan PTU) dan pengukuran ketiga pada hewan uji yang telah diberi terapi. Pengukuran ketiga dilakukan pada seluruh kelompok perlakuanyang bertujuan untuk mengetahui adanya penurunan kadar trigliserida yang telah diberikan. Hasil pengukuran kadar trigliserida awal, induksi, setelah perlakuan dan selisih penurunan kadar trigliserida tikus dapat dilihat pada tabel I berikut.

Tabel I. Pengukuran kadar trigliserida awal, induksi, setelah perlakuan dan selisih penurunan pada tikus putih wistar jantan

\begin{tabular}{|l|c|c|c|c|}
\hline \multirow{2}{*}{ Kelompok } & \multicolumn{3}{|c|}{ Kadar Rata-Rata Kadar Trigliserida } & \multirow{2}{*}{$\begin{array}{c}\text { Rata-rata Selisih } \\
\text { (mg/dL) } \\
\text { Penurunan } \\
\text { Trigliserida } \\
\text { (mg/dL) }\end{array}$} \\
\cline { 2 - 4 } & Awal & Induksi & $\begin{array}{c}\text { Setelah } \\
\text { Perlakuan }\end{array}$ & $-31,83$ \\
\hline $\begin{array}{l}\text { Kontrol negative } \\
\text { Na.CMC 0,5\% }\end{array}$ & 122,16 & 340 & $371,83^{\mathrm{b}}$ & 88,5 \\
\hline $\begin{array}{l}\text { Kontrol positif } \\
\text { Atorvastatin 0,149 } \\
\text { mg/kgBB }\end{array}$ & 115,83 & 271,33 & $182,83^{\text {a }}$ & \\
\hline $\begin{array}{l}\text { Ekstrak } \\
\text { terpurifikasi batang } \\
\text { galing } \\
500 \mathrm{mg} / \mathrm{kg} \text { BB }\end{array}$ & 120,66 & 269 & $168,83^{\text {a }}$ & 100,16 \\
\hline
\end{tabular}

$\mathrm{a}=$ berbeda signifikan dibandingkan terhadap kontrol negatif $(\mathrm{p}<0,05)$

$\mathrm{b}=$ berbeda signifikan dibandingkan terhadap kontrol positif $(\mathrm{p}<0,05)$

Tabel I di atas menunjukan selisih penurunan kadar trigliserida darah tikus putih yang diberikan ekstrak terpurifikasi batang galing dosis $500 \mathrm{mg} / \mathrm{kg}$ BB yaitu 100,17 mg/dL. Penurunan kadar trigliserida juga menunjukan penurunan pada kontrol positif (Atorvastatin $0,149 \mathrm{mg} / \mathrm{kg} \mathrm{BB}$ ) yaitu $88,5 \mathrm{mg} / \mathrm{dL}$ sedangkan pada pemberian kontrol negatif $\mathrm{Na}$. CMC $0,5 \%-31,83 \mathrm{mg} / \mathrm{dL}$. Berdasarkan tabel I, hasil penelitian setelah perlakuan selama 7 hari menunjukan adanya penurunan kadar trigliserida pada tikus putih yang mengalami hiperlipidemia setelah pemberian kontrol positif dan ekstrak terpurifikasi batang galing 500 $\mathrm{mg} / \mathrm{kg}$ BB. Sedangakan pada pemberian kontrol negatif tidak mengalami penurunan atau mengalami peningkatan kadar trigliserida. 
Pada uji analisa data secara statistik menggunakan metode analisa varian satu arah (One way-Anova) pada aplikasi SPSS 16.0 menunjukkan adanya perbedaan signifikan seluruh kelompok perlakuan dengan nilai 0,00<0,05 maka dilanjutkan dengan uji Post Hoc LSD untuk menentukan kelompok mana saja yang memberikan nilai yang signifikan dengan kelompok lainnya terhadap penurunan kadar trigliserida pada tikus putih wistar jantan seperti pada tabel II berikut.

Tabel II. Uji Post Hoc LSD penurunan kadar trigliserida antar kelompok

\begin{tabular}{|c|c|c|c|}
\hline Kelompok & Kelompok & Nilai Sign & Kesimpulan \\
\hline \multirow{2}{*}{$\begin{array}{l}\text { Kontrol negatif Na.CMC } \\
0,5 \%\end{array}$} & $\begin{array}{l}\text { Kontrol positif (Atorvastatin } \\
0,149 \mathrm{mg} / \mathrm{kgBB})\end{array}$ & $0.000<0.05^{*}$ & Berbeda signifikan \\
\hline & $\begin{array}{l}\text { Ekstrak terpurifikasi batang } \\
\text { galing } 500 \mathrm{mg} / \mathrm{kgBB}\end{array}$ & $0.000<0.05^{*}$ & Berbeda signifikan \\
\hline \multirow{2}{*}{$\begin{array}{l}\text { Kontrol positif } \\
\text { Atorvastatin } 0,149 \\
\mathrm{mg} / \mathrm{kgBB}\end{array}$} & $\begin{array}{l}\text { Kontrol negatif Na.CMC } \\
0,5 \%\end{array}$ & $0.000<0.05^{*}$ & Berbeda signifikan \\
\hline & $\begin{array}{l}\text { Ekstrak terpurifikasi batang } \\
\text { galing } 500 \mathrm{mg} / \mathrm{kgBB}\end{array}$ & $0.186>0.05$ & $\begin{array}{l}\text { Tidak berbeda } \\
\text { signifikan }\end{array}$ \\
\hline \multirow{2}{*}{$\begin{array}{l}\text { Ekstrak terpurifikasi } \\
\text { batang galing } 500 \\
\mathrm{mg} / \mathrm{kgBB}\end{array}$} & $\begin{array}{l}\text { Kontrol negatif ( Na.CMC } \\
0,5 \%\end{array}$ & $0.000<0.05^{*}$ & Berbeda signifikan \\
\hline & $\begin{array}{l}\text { Kontrol positif (Atorvastatin } \\
0,149 \mathrm{mg} / \mathrm{kgBB} \text { ) }\end{array}$ & $0.186>0.05$ & $\begin{array}{l}\text { Tidak berbeda } \\
\text { signifikan }\end{array}$ \\
\hline
\end{tabular}

Keterangan : * berbeda signifikan (taraf kepercayaan 95\%)

Berdasarkan uji Post HocLSD didapatkan bahwa kelompok kontrol negatif Na.CMC $0,5 \%$ memiliki perbedaan yang signifikan dengan kelompok kontrol positif atorvastatin 20 $\mathrm{mg}$ dan kelompok ekstrak batang galing $500 \mathrm{mg} / \mathrm{kgBB}$. Kelompok kontrol positif Atorvastatin $0,149 \mathrm{mg} / \mathrm{kgBB}$ memiliki perbedaan yang signifikan dengan kelompok kontrol negatif Na.CMC 0,5\% tetapi tetapi tidak memiliki perbedaan yang signifikan dengan kelompok perlakuan ekstrak terpurifikasi batang galing $500 \mathrm{mg} / \mathrm{kgBB}$, artinya ekstrak terpurifikasi batang galing memiliki efek penurunan kadar trigliserida pada tikus putih wistar jantan yang sama penurunannya dengan atorvastatin.

Penurunan kadar trigliserida serum darah pada kelompok dosis uji dapat terjadi akibat efek dari senyawa yang terdapat pada ekstrak terpurifikasi batang galing yaitu flavonoid (Yusuf dkk., 2018). Flavonoid dapat menurunkan sintesis kolesterol dengan cara menghambat kerja dari HMG-CoA reduktase, yang merupakan enzim yang berperan dalam pembentukan kolesterol di hati. Selain itu, flavonoid juga dapat menurunkan aktivitas enzim acyl-coA cholesterol acyltransferase (ACAT), yang merupakan enzim yang berperan dalam pengaturan absorbsi kolesterol di usus dan produksi lipoprotein di hati (Maryani dkk, 2016). Kandungan flavonoid juga dapat meningkatkan hidrolisis lipid oleh enzim lipase sehingga asam lemak, monogliserida, kolesterol diabsorpsi lewat sel mukosa usus dan lipid dapat keluarkan bersama feses yang mengakibatkan kadar kolesterol dan trigliserida menurun (Sudheesh, 1999). Hal ini sejalan dengan penelitian yang dilakukan oleh Ilyas (2017) dimana pemberian ekstrak etanol daun galing memiliki efek penurunan kadar kolesterol darah mencit yang mengalami hiperlipidemia dengan dosis efektif $500 \mathrm{mg} / \mathrm{kgBB}$.

\section{KESIMPULAN}

Ekstrak terpurifikasi batang galing (Cayratia trifolia L. Domin) dosis $500 \mathrm{mg} / \mathrm{kgBB}$ memberikan efek penurunan kadar trigliserida pada tikus putih wistar jantan yang mengalami hiperlipidemia yang tidak berbeda signifikan dengan kontrol positif $(p>0,05)$.

\section{DAFTAR PUSTAKA}

Dewi, R. Y., Santoso, M.L. 2013. Uji Efektifitas Air Perasan Buah Nanas (Ananas comosus (L.) Merr.) Terhadap Kadar Kolesterol Total dan Trigliserida Darah Mencit (Mus 
musculus) Serta Sumbangannya Pada Pembelajaran Biologis Di Sekolah Menengah Atas (Jurnal Penelitian).

Guyton, A. C. 1997. Fisiologi Manusia dan Mekanisme Penyakit. Penerbit Buku Kedokteran EGC. Jakarta.

Ilyas Y., Muhammad, Marcelinda, A., Saehu, M.S. 2017. Efek Ekstrak Etanol Daun Galing (Cayratia trifolia L.Domin) Terhadap Penurunan Kadar Kolesterol Total Darah Pada Mencit Hiperlipidemia. Warta Farmasi, 6(2);1-9.

Ilyas, Y.M, Firdayanti, dan Wahyuni. 2019. PeningkatanImunitas Non Spesifik (Innate Immunity) Mencit Balb/C Yang Diberi Ekstrak Etanol Daun Tumbuhan Galing (Cayratia trifolia L. Domin). Jurnal Medical Sains, 3(2),83-92.

Kahono, J.Y. 2010. Pengaruh Ekstrak Herba Meniran (Phyllantus niruri L.) terhadap Kadar Trigliserida Darah Tikus Putih (Rattus norvegicus). Universitas Sebelas Maret

Kumar D, Gupta J, Kumar S, Arya R, Kumar T, Gupta A. 2012. Pharmacognosyic evaluation of Cayratia trifolia (Linn) leaf. Asian Pac J Trop Biomed 2012;2:6-10.

Lynch's, 1993. Medical Laboratory Technology, Forth Edition, WB, Saunders Company Philadelphia.

Maryani P E., Ulfa E U., Ema R. 2016. Pengaruh Ekstrak Metanol Daun Kayu Kuning (Arcangelisia flavaL. Merr.) Terhadap Kadar Kolesterol Total Dan Trigliserida Tikus Hiperlipidemia. Jawa Timur : Fakultas Farmasi Universitas Jember.

Malik, A. 2014. Pengujian Aktivitas Antioksidan Ekstrak Terpurifikasi Daun Teh Hijau Dan Jati Belanda. Jurnal Fitofarmaka Indonesia Vol. 4. No 2. Fakultas Farmasi, Universitas Muslim Indonesia..

Nofianti, T , Windiarti, D, Prasetyo Y. 2015. Uji Aktivitas Ekstrak Etanol Krop Kubis Putih (Brassica oleracea L.var. capitata) Terhadap Kadar Kolesterol Total Dan Trigliserida Serum Darah Tikus Putih Jantan Galur Wistar. Jurnal Kesehatan Bakti Tunas Husada.

Pratiwi, A.P. 2016. Aktivitas antibakteri ekstrak daun singkong (Manihot esculenta crantz.) TerhadapShigella sp.Jurnal kesehatan, PangkalPinang.

Pykalisto, O. Goldberg, A, Brunzell, JD. 1976. Reversal of decreased human adipose tissue lipoprotein lipase and hypertriglyceridemia after treatment of hyperthyroidism. J Clin ndocrinol Metab :549.

Roat, C., Kumar, N and Ramawat, KG. 2008. Occurrence of Stilbenes inUnorganized Cultures of Cayratia trifolia (L.) Domin. Journal of Herbal Medicine and Toxicology 2 (1) 11-15 (2008) ISSN : 09734643.

Singh, S., Mann, R., dan Sharma KR. 2012. Phytochemical Analysis and Pharmacognostical Standardization of stem of Cayratia trifolia (Linn.) Domin. Int J Pharm Sci Res. 3 (11); 4503-4506.

Susanti, A., Fernando, A., Adelin, I. 2014. Efek Analgetik Ekstrak Etanol Daun Tampa Badak (Voacanga foetida (BI.) K. Scum) Pada Mencit (Mus musculus) Jantan. Jurnal Sains Farmasi dan Klinis

Skeggs, J. W. dan Morton, R.E. 2002. HDL and LDL enriched in tryglyceride promote abnormal cholesterol transport. J. Lipid Res. 43: 1264-1274.

Sudheesh, S., Sandhya, C., Sarah, A., And Vijayalakshmi, N. R. 1999. Antioxidant activity of flavonoids from solanum melongena.Phytotherres. 1999 aug; 13(5): 393-6.

Shin, D. J dan Osbone, T.F. 2003. Thyroid hormone regulation and cholesterol metabolism are connected through sterol regulatory element-binding protein-2 (SREBP). Journal Biology Chemistry., $278:$ 34114-34118.

Yusuf, M.I., Wahyuni., Susanty, S., Ruslan., Fawwaz, M. 2018. Antioxidant and Antidiabetic Potential of Galing Stem Extract (CayratiatrifoliaDomin). Pharmacog Journal.;10(4):686-9.

Zou, Y.,Y. Lu dan Wei, D. 2005. Hypocholesterolemic effects of a flavonoid-rich extract of hypericum perforatum L.in rats fed a cholesterol-rich diet. J. Agric, and Food Chem. 53 (7):2462-2466. 
